UDC: $371.3:: 811.163 .41$

$371.3:: 82$

Јована Н. Давидовић

Филозофски факултет - докторске студије Методике наставе, Нови Сад jovana.davidovic@yahoo.com

\title{
БОРИСАВ СТАНКОВИЋ И ИВО АНДРИТ У СВЕТЛУ НОВОГ НАСТАВНОГ ПРОУЧАВАЊА
}

\author{
Апстракt
}

У фокусу рада је компаративно проучавање збирке приповедака Божји људи Борисава Станковића и приповедака Hanacm и Cмрт y Синановој текији Иве Андрића. Компаративна анализа проучава утицај митске слике света и традиционалне културе у овим делима. Рад се бави простором и временом као основним категоријама митске слике света. Трагови традиционалне културе проналазе се у бинарној опозицији црно-бело, али и у заштитној улози камена и његовој способности да за себе веже душе умрлих. Рад, такође, пореди Станковићеве божјаке и Андрићеве божје људе. На крају 'стоје' жене на капији. Као такав, рад представља нов начин наставне обраде књижевног дела ова два писца.

Кључне речи: митски простор, митско време, бело-црно, камен, божјаци, божји људи, жена на капији, настава, методика.

\section{1. УВОД}

Компаративна анализа Станковићеве збирке приповедака Божји људи и Андрићевих приповедака Смрт у Синановој текији и Напаст омогућава нову наставну обраду књижевног стваралаштва поменута два писца. Упознавање ученика са компаративном књижевном анализом уводи их у модерне токове науке о књижевности. Заједно са осталим модерним методама књижевне анализе, компаративна анализа тежи да „овлада богатом ризницом знања и искуства [...] са циљем што потпунијег истраживања прошлости и савремености" (Деретић 2007: 187). Са друге стране, она освежава наставно градиво делима која су остала изван наставног програма. Решење за стишавање одбојности ученика према настави српског језика и књижевности, лежи управо у „иновирању програма овог наставног предмета" (Илић 2006: 670). 
Оваква наставна обрада представљала би право књижевно истраживање, у коме би главну улогу преузели ученици. Истраживачка наставна метода подстиче креативност и истраживачки дух ученика. Они постају активни учесници, а не пасивни слушаоци. Развија се њихово самопоуздање, подстичу се да слободно износе своје мишљење.

Ученици би се, поред усвајања знања о књижевности, упознали и са основним елементима митске слике света и традиционалне културе. На тај начин се, осим развијања љубави према књизи и развијања читалачких навика, подстиче њихово интересовање за прошлост и ствара веза са традицијом, која је у модерном времену запостављена.

Компаративна књижевна анализа у наставу уноси иновативност, која има за циљ да ученике заинтересује за градиво, али и да их окрене књизи, како би дошли до превазилажења тзв. кризе читања:

„Криза читања јесте „првенствено [...] сложен, комплексан, педагошки проблем [...] Сигурно је да читање или нечитање књига проблем који мора да интересује и област културе па је то крупан културолошки проблем [...] Криза читања, посебно због негативног утицаја на васпитање младих, постаје посве озбиљан и општедруштвени проблем. Мора се поставити питање какав ће бити будући грађанин, какво читаво друштво у коме се потискује књига, а с њом и укупно културно стваралаштво и његово наслеђе" (Илић 2009: 19).

С обзиром на то, да „за живот и рад изузетан значај има љубав према књизи и читању, јер добра књига има велику моћ, уноси лепоту и снагу у човеков дух, буди радозналост, учи да се воли свет" (Маринковић 2003: 209), развијање љубави према књизи и читању један је од основних задатака модерне школе. „Најчешће се дешава да ученици не доживе лепоту и снагу текста, да прођу углавном мимо њих" (Маринковић 2003: 211). Површност и неефективна тумачења занемарују основни циљ наставе књижевности, а то је стварање љубави према уметничкој књизи.

Традиционална настава од ученика захтева да усваја знања из наставниковог предавања или уџбеника, да их памти и касније репродукује. „Једини критеријум истине је наставникова реч” (Маринковић 2003: 11). Наставник је тај који се труди да часове ,испуни својим говором, мислима и оценама” (Маринковић 2003: 11), потискујући на тај начин самосталност и креативност ученика. Мишљење за ученика у традиционалној настави је „навика, а не способност” (Маринковић 2003: 11).

Модерна школа жели да промени такву слику. Она тражи ученике истраживаче. Не бомбардује их готовим знањима, него их води путем открића 
информација и знања. Њено кључно одређење је ,афирмација стваралаштва наставника и ученика у васпитно-образовном просецу" (Маринковић 2003: 11).

Наставник у модерној, креативној настави ,је пре свега у позицији организатора, човека који мотивише, моделира, помаже, истражује, иницира, подстиче, усмерава и стално трага за новим видовима организације" (Маринковић 2003: 19), „особа која је ученик” (Мајл 1968: 171). „Захтеви који се стављају пред наставнике и школе су све сложенији" (Пантић 2010: 11). Школски системи свих земаља теже да побољшају своје школе. Пошто су најважнији ресурси у школама, наставници имају централну улогу у напорима за унапређење школовања. Наставници би требало да ученике припреме за живот у коме се од њих очекује да буду „самоиницијативни, способни и мотивисани да уче целог живота” (Пантић 2010: 11).

Бројне су последице предавања ex catedre:

„Приповедачево припремање за час из овешталих и давно написаних књига, доминантна улога професора и пасивна позиција ученика који се клоне сарадње, ретко постављају питања, плашећи се да тако не покажу властите заблуде или неприпремљеност за час, затомљавајући интересовања и ставове који се не подударају са професоровим, чести су призор на школској сцени. [...] Последице такве наставне праксе je немогуће побројати, а кулминирају у обостраном незадовољству: професора јер су незадовољни пасивним ученицима, а ученика јер им је досадно на часу, јер добијају утисак да немају утицај на креирање наставе, јер им није дата реч ни могућност активног укључивања у осмишљавање часова” (Радуловић 2011: 133).

Стога је јако важно да у средишту модерне наставе књижевности буде књижевно дело, а њен основни задатак тумачење естетских и етичких вредности уметничког текста.

„У складу са општом тенденцијом савремене педагогије да ученик мора да буде активни учесник у настави, њен субјекат, и методика наставе тражи да се ученик активно укључује у откривање и тумачење вредносних чинилаца уметничког текста, да о њима на часу, расправљајући о литерарним проблемима, укрсти своје мишљење с друкчијим мишљењима, да своје ставове брани или коригује, и тако сопственом свешћу реципира ширину и богатство значења текста о коме се расправља. Тек у таквом судару сопствене свести с књижевним делом, дело остварује своје пуно деловање на свестран духовни развој младе личности. Тиме се васпитно-образовни задаци ове наставе остварују у пуној мери” (Илић 2009: 7). 
Наставу треба осмислити тако да ученик својим истраживањем самостално осваја знања: „Ученик не прима готова сазнања, већ до њих сам долази" (Гајић 2009: 298).

Напори који наставни кадар улаже како би се превазишла криза читања огледају се у примени нових методологија, које су основа савремених тенденција у настави. Једна од њих свакако је примена компаративне књижевне анализе. Поређење Станковићевих и Андрићевих дела пружа могућности да се узајамно осветле лепота и сложеност њихових дела, иновира настава књижевности, омогућавајући квалитетнију и ефектнију наставну обраду, подстичући стварање читалачких навика и љубави према књизи, што је један од главних задатака наставе књижевности.

\section{2. НЕКИ РЕФЛЕКСИ ТРАДИЦИОНАЛНЕ КУЛТУРЕ У} ПРИПОВЕТКАМА НАПАСТ И СМРТ У СИНАНОВНОЈ ТЕКИЈИ ИВЕ АНДРИЋА И У ЗБИРЦИ ПРИПОВЕДАКА БОЖЈИ ЉУДИ

\section{БОРИСАВА СТАНКОВИЋА}

„Књижевно дело Борисава Станковића [...] несумњиво је превратничко [...] Настало на размеђи традиционалног и модерног” (Пешикан 2005: 431). Он је значајно иновирао српску реалистичку приповетку. Отворио је врата модерне српске приповетке, кроз која ће, не задуго потом, проћи Иво Андрић, мајстор приче и приповедања. Можда их је управо љубав према причи и приповедању и вера у њену моћ учинила пријатељима и поред знатне разлике у годинама. Приповедачки дух их је спојио.

Синиша Пауновић је у свом дневнику забележио пријатељство Иве Андрића и Борисава Станковића: „Једини млађи писац који га је посећивао ${ }^{1}$ и тиме се некако поносио био је Иво Андрић. У библиотеци је имао Немиpe и Ex Ponto које му је Андрић поклонио, као и чувену новелу Пут Алије Ђерзелеза". ${ }^{2}$ Поред тога, Пауновић је својим белешкама додао и Андрићеве речи:

„Не желим да упоређујем себе с Бором [...] али између нас има пуно сличности, и у животу, и у литератури. Добро сам познавао Бору Станковића и лично... Нас двојица смо се виђали врло често, од 1919. године наовамо. Био је сиромашно дете. Син малог занатлије. И његов отац је, изгледа, рано банкротирао због промене власти - код њега турске, код мене аустроугарске. И њему је умро отац, вероватно од исте

1 Мисли се на Борисава Станковића.

2 Приступљено 3. 1. 2013. http://riznicasrpska.net/knjizevnost/index.php?topic=403.0 
болести - сушице. И њега су рођаци гајили и школовали - њега баба по оцу, мене тетка по мајци. И он је кадио очи по туђим књигама - он на књигама својих професора Симића и Продановића, ја на књигама својих суседа аустроугарских официра у Вишеграду и по излозима књижара у Сарајеву. И он из немаштине умало да није отишао на занат и прекинуо школовање. Места у којима смо провели своја детињства и добар део младости била су некад на граници, једно Турске, друго Аустро-Угарске [... ] И у погледу студија ми смо имали сличности: желео је да студира књижевност, а свршио је права; ја сам студирао књижевност, а отишао у дипломате. Па и у погледу чиновничке каријере имали смо извесне сличности [...] И њега су врло рано прихватили и публика и критичари као нешто ново, дотле невиђено, необично [... ] И по свом лику имали смо неке сличности. Први ми је скренуо пажњу на нашу тамну, 'азијатску' пут, како је говорио источњачку, коју сам временом и сам приметио. И као писци, у погледу мотива, и типова, и стила, имали смо доста сличности; он то у целости није приметио, јер сам ја своја најважнија дела написао после његове смрти; али је често говорио о Вишеграду као да помиње своје Врање. Ми смо, по моме мишљењу, слични особито и по томе, да парафразирам неке наше заједничке тумаче и критичаре, што смо обојица регионалном мотиву дали свељудску боју и психологију". ${ }^{3}$

У напору да се осветли веза ова два писца, нарочито када је реч о положају жене, као предмет компаративне анализе биће узети Станковићева збирка приповедака Божји људи и Андрићеве приповетке Смрт у Синановој текији и Hanacm. Осим тога веза се може успоставити и тематски преко лика божјака и божјих људи.

Станковићеви јунаци су божјаци, чија „социјално-економска маргинализованост извире из религијске лиминалности и утапа се у њу" (Пешикан 2005: 433). Убог или божјак, у преводу просјак, говори у прилог старом веровању да „просјак може бити какво божанство” (Чајкановић 1973: 71). У многим словенским језицима реч просјак и предак воде порекло од исте речи. Култ просјака ствара паралелу са култом предака, који представља главну карактеристику старе српске религије. Према Бојану Чолаку, Станковићеви мушки јунаци су „психички дементни” (Чолак 2011: 305), они су такви од рођења или их до психичких поремеђаја доводе неке необјашњиве околности, међутим приче о њима имају „отворен завршетак, они настављају да живе" (Чолак 2011: 305).

3 Приступљено 3. 1. 2013. http://riznicasrpska.net/knjizevnost/index.php?topic=403.0 
Божји људи које срећемо код Андрића су, насупрот томе, свештена лица, „мушкарци који су се одрекли световног живота” (Детелић 2000: 251), па су тиме маргинализовани. Разлика међу њима јесте у томе, што је у приповеци Смрт у Синановој текији Алидеде оличење светости, фигура према којој остали осећају поштовање, неко ко се „прочуо надалеко због своје учености и светости” (Андрић 2008: 157), док је у Напасти фра Стјепан „безазлен и неугледан фратар" (Андрић 2008: 161), предмет подсмеха. По односу других према фра Стјепану, његова фигура унеколико је блиска Станковићевим божјацима. Обојици им је, ипак, заједничка стрепња и несналажење у сусрету са женом, око које се граде обе приповетке.

\section{1. Митски простор}

Простор је једна од две основне категорије митске слике света. Према мишљењу Мирјане Детелић, митски простор представља „низ места неједнаке означености и изузетног значаја" (Детелић 2000: 246), свака тачка у том низу постаје „место-знак” (Детелић 2000: 246), који „даље може служити за означавање других, непросторних категорија" (Детелић 2000: 246). Осим тога, ова ауторка истиче и интерност (Детелић 2000: 246) и темпоралност (Детелић 2000: 246) као важне одлике митског простора. Све оне су умногоме утицале на формирање слике света, одређене бинарним опозицијама: отворено-затворено, унутра-напољу, своје-туђе, добро-зло, живот-смрт. У таквим разграничењима, јасно је, границе су играле јако важну улогу.

Што се тиче простора свакодневице, људске куће, он је био уситњен до највеће могуће мере, како би био што ефикаснији. Тако се простор куће, која се сматра апсолутно својим простором, дели и вертикално (у односу на огњиште) и хоризонтално (у односу на праг). Насупрот кући, која је сматрана апсолутно својим простором, шума је била апсолутно туђи простор. Између њих налазили су се: окућница, башта, двориште, њива, ливада, воћњак/ виноград. Свака та подела доносила је нове границе, које су морале додатно да се штите. Највећу заштиту захтевала су кућна врата и капија, јер су штитиле апсолутно свој простор.

Наза се налази на почетку низа божјака, на самој граници њиховог простора „Иза гробља, до реке, живела је она. Испочетка у рупи, доцније начинивши колебу. И сваким даном је све више покривала" (Станковић 1991: 17). Својом вредноћом Наза је обезбедила себи заштићени простор.

Граница, тј. лиминалност простора управо је оно што повезује Станковићеву збирку и Андрићеве приповетке. „Свети и нечисти простор границе $[\ldots .$.$] придаје људима који га насељавају улогу медијатора, посредника између$ 
света живих и света мртвих" (Пешикан 2005: 433). Иако наведени цитат говори о Станковићевој збирци приповедака, са лакоћом се може повезати и са Андрићевим приповеткама.

Станковићеви људи живе у кризном простору границе. У истом положају су и Андрићеви јунаци. Андрићев Алидеде не прелази границу, остаје иза затворених врата, док недовољно заштићена фра Стјепанова врата прелази непозната девојка: „Глава и рамена су јој прелазили праг. И да је хтео није их више могао затворити" (Андрић 2008: 162). Оба Андрићева јунака се кају због својих поступака. По овоме се Андрић уклапа у балкански модел света „коме категорије директан, једнозначан и одређен никако не одговарају" (Детелић 2000: 258). С друге стране, као и Станковићева Наза у односу на божјачки простор, жене у обе Андрићеве приповетке налазе се изван простора јунака, на маргини.

\section{2. Митско вРЕМЕ}

Митско време је, такође, „основна категорија митске слике света”

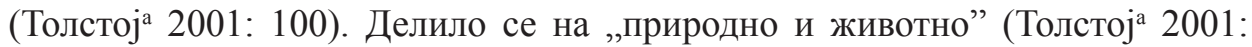
100). Свако од њих делило се и „на оно са „позитивним и оно са „негатив-

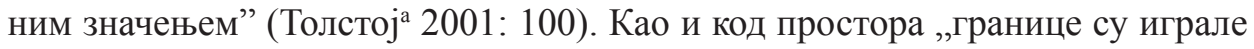
важну улогу и захтевале су посебну заштиту” (Толстоја 2001: 100).

Жене су код Андрића двоструко угрожене, али и двоструко опасне. У глуво доба ноћи налазе се на отвореном, на улици, изван свог простора, а притом су полуголе. Ноћ је „неповољно доба, везано са тамом, мраком и смрћу, са болешћу и присуством демона” (Бајић 2008: 33). „Време око поноћи назива се ниједним добом, јер се тада појављују зла натприродна бића" (Братић 1993: 30). „Највећу опасност по људе носи доба од поноћи до зоре. То је време разузданости нечистих сила" (Толстој ${ }^{a}$ 2001: 101). Из тог разлога: „за ноћно доба је везан велики број забрана” (Плотникова 2001: 390). Једна од најважнијих јесте да се ноћу не напушта кућа како не би дошло до контакта са нечистим силама. Ноћу је потребно ,редуковати све послове ван куће” (Братић 1993: 29). „Сигурност и заштиту могуће је остварити једино у топлом дому, тј. треба се држати свог огњишта" (Братић 1993: 29). Контакти су дозвољени само „са припадницима истог домаћинства” (Братић 1993: 30). Кретање по ноћи доноси и „могућност завођења са правог пута” (Братић 1993: 66). Основна својства ноћи су „тишина и тама” (Братић 1993: 66). Тама је заиста „опасан непријатељ човека” (Братић 1993: 69). „Судари са тамом доводе до страдања или потпуне трагедије” (Братић 1993: 69). 
Понашање жена у обе Андрићеве приповетке је у митском свету сасвим нерегуларно. Њихова појава везана је за ноћ, и то ноћ без месеца. „Помрчина, време без месечине, која је претходила појави младог месеца, сматрана је за крајње неповољно и опасно доба, као и свака просторна и временска граница” (Толстој ${ }^{6}$ 2001: 355). Веровало се да „у време помрчине месец осветљава загробни свет" (Толстојб 2001: 355). Таква ноћ довела је жене у обе Андрићеве приповетке. Обе би могле бити нечисте силе. С друге стране, и оне саме су незаштићене, изложене дејству нечистих сила и треба им помоћ коју траже. У том противречју оцртава се амбивалентни однос мушких ликова према жени, који подразумева страх и одбојност, с једне стране, и забрањену привлачност, с друге стране.

Код Станковића је честа слика месечине. Месец и његова светлост везују се у митској слици света „за загробни свет и смрт” (Толстој ${ }^{б} 2001$ : 354). Месец, господар ноћи сматра се „божанством смрти” (Братић 1993: 153).

„Злослутна снага месеца у причи је изражена представом о Бекчету као месечару, када се алудира на његову опседнутост демоном. Повезивање животног удеса и наговештене смрти божјака са небеским светлилом може да има своју паралелу у народним представама о месецу који, како држе Срби и Македонци, 'пије човеков живот' и о штетности месечине. Раширено је веровање да месец привлачи душе покојника, односно да је месец област смрти. Сви Словени су, такође, сматрали да је месечева светлост опасна, посебно за децу и труднице. Месец расте, смањује се, нестаје, у народној машти га прождире чудовиште, или је сам чудовиште које великим ждрелом исисава крв проливену на земљу, па му се, зато, придаје злокобна моћ. Погубни утицај месеца и лунарна катастрофа, коју производи, представљени су као узрок смрти Станковићевог божјака. Тако је у причи, као и шире у књижевности и фолклору, месец епифанија смрти" (Бајић 2008: 33).

Осим у новели Бекче месечину срећемо и у новели Марко: „А кад извара слуге и искраде се од њих онда појури као суманути и бежи, јури онако блед, у кошуљи по улицама, чаршији, те се од њега свет грози и смеје. А то га снађе у ноћима са јаком месечином" (Станковић 1991: 74).

\section{3. БЕЛА И ЦРНА БОЈА}

Боја је у народној култури један од основних елемената који карактерише „читав низ обредних симбола [...] Симболика беле и црне боје, које се 
налазе на поларним тачкама спектра боја, јесте антиномична" (Белова 2001: 43). Бинарна опозиција бело-црно може се повезати са низом других опозиција: „добар-зао, живот-смрт, мушки-женски” (Белова 2001: 43). Често је „симболика боја амбивалентна” (Белова 2001: 43). Бела боја може истовремено да означава „и сакралност, чистоту, плодност, светост, али и да буде веза са оностраним" (Белова 2001: 43). У веровањима многих словенских народа „смрт има лик девојке у белој одећи” (Белова 2001: 43). То се подудара са сликом жене на капији у Андрићевој приповеци Cмрт у Cuнановој текији: „То је била нека жена у белој хаљини или само у кошуљи” (Андрић 2008: 159). Мртвац је код Станковића је умотан у „чисто бело платно” (Станковић 1991: 86) и положен „на белом чаршаву” (Станковић 1991: 86).

„Најконкретнију и једнозначну симболику има црна боја, која асоцира на мрак, земљу и смрт [...] Црне боје су обично демонски ликови” (Белова 2001: 44).

Опозиција црно-бело видљива је у Станковићевом грађењу ликова Назе и Љубе. Бела боја у овом пару је Наза, која је ,увек била опрана, искрпљена као и лепо повезана" (Станковић 1991: 18), а црно је Љуба који је „увек ишао у дугачкој, пртеној кошуљи, коју нити је прао, нити свлачио док је не поцепа" (Станковић 1991: 18).

\subsection{KAMEH}

Камен је ,један од праелемената света” (Левкиевска 2001: 257) и „елеменат је мртве природе” (Левкиевска 2001: 258). Постоји веровање да је пре потопа ,камен имао особине живих бића” (Левкиевска 2001: 257), као и да су у камену утиснути трагови Божјих стопала и стопала светаца. С обзиром на његову тврдоћу, камен се у традиционалном поимању света везује за „мушко начело” (Левкиевска 2001: 258). Према примитивном веровању ,душа после смрти може ући у камен” (Чајкановић 1994: 82), а камени надгробни споменици „спречавају одлазак душе покојника из гроба” (Чајкановић 1994: 91). Често се камен, с обзиром на то да је симбол мртве природе, узима као „боравиште демона” (Левкиевска 2001: 258). Дакле, поред тога што се камен сматра „стаништем какве душе” (Чајкановић 1994: 166), он може бити и „,едиште моћнијих демона и божанстава" (Чајкановић 1994: 166). У традиционалном свету морални преступници кажњавани су каменовањем. Ношење камена уз себе била је казна за прељубника, камен је био симбол његовог проклетства.

Камен проналазимо и код Станковића и код Андрића. У приповеци Луди Стеван, главни лик Стеван: „Увек, где год је ишао, по чаршији, улици, 
вукао је камење и трпао у њедра и појасеве [...] Па кад накупи, онда све одвуче и нанесе где је била црква" (Станковић 1991: 78). Ношење камена може бити испаштање кривице предака због које Стевану уз име у наслову стоји епитет луди. Камење је као знак срамоте са собом морао носити прељубник. Станковић нас, међутим, у овој епизоди не упознаје са Стевановим пореклом или његовом прошлошћу. Епитет који стоји уз његово име у наслову новеле могао би бити начин на који су други доживљавали ову Стеванову необичну навику. С друге стране, Стеван је то камење носио на место где је била црква, а као што је већ речено постоји веровање да су у камењу утиснута Божја стопала и стопала светаца. То камење могло би да преузме улогу цркве док се не подигне нова, јер у традиционалној култури јавља се и поштовање култног камена. Цркву су први пут срушили Турци. Стеваново камење штитило је простор на коме ће бити сазидана црква, јер камен управо има велико заштитно дејство. Камен би својом постојаношћу, могао бити и порука да црква и даље постоји, иако нема своју грађевину. Након што је подигнута црква Стеваново камење остало је као путања која води од порте до цркве, штитећи и даље овај свети простор. Стога би камен, који је Стеван доносио на место на коме је била црква, могао најпре бити „камен темељац” (Чајкановић 1994: 148), а касније „камен старац” (Чајкановић 1994: 148), заштитник огњишта.

Двориште у Синановој текији било је сво од камена. Управо на том камену Алидедин одлазак је започео. Тај камен везао је његову душу. Осим тога, жена из цариградске ноћи лежала је „на великој каменој плочи” (Андрић 2008: 159). С друге стране, камена плоча појачава алегорију смрти, која започиње ликом девојке у белој кошуљи. Камен на коме лежи, везао је њену душу за себе, а везао је осећањем кривице и стида и Алидедину душу.

\section{5. ЖЕНА НА КАПИЈИ}

Жене су код Станковића такође божјаци, међутим њихова улога појачана је ,архајском представом о жени као бићу са маргине, могућој видилици и посредници између два света" (Пешикан 2005: 433). Тако су на Задушнице на гробље излазиле само жене. „На тај дан [...] мушки не иду на гробље [...] Од жена не може да се прође” (Станковић 1991: 7-8).

Андрићева мисао: „Жена стоји, као капија, на излазу као и на улазу овога света" (Андрић 2008: 160), не остаје само у оквирима приповетке Смрт у Синановој текији. Она се готово природно надовезује на Станковићеве божјакиње. Жене на капији нашле су своје место и на последњим страницама Станковићевог дела: 
„Убрзо затим почеше да долазе из комшилука остале старе жене [...] Затим кад се све искупише, одоше у кујну где је мртвац био однесен. И пошто га тамо окупаше, уредише, као сваког мртваца [...] саме изнеше горе и унеше у собу. И пошто га, испод иконе, на белом чаршаву полако, нежно наместише, онда га свака, прекрстивши се, целива у чело, запали му свећу више главе, и после се поређаше око њега да седе, чувају га [...] И тако би оне целе ноћи преседеле око њега мртвог, осветљеног, пазећи, чувајући га и чекајући да дан сване $[$ [...]" (Станковић 1991: 85-86).

Лик клисарице, такође, говори о жени као граничном бићу, жени ближој смрти: „Управо клисарица је била прави клисар, а њен муж, неки миран, слабуњав човек, само је копао гробове, а све остало, што је најтеже [...] све је то она, жена му радила" (Станковић 1991: 13).

Психички поремећаји „жена код Станковића [су] мотивисани и благи” (Чолак 2011: 305). Оне су у свету божјака нашле „утеху од суровости света” (Чолак 2011: 306). Наза је побегла од газде који је хтео да је силује. Вејка је побегла од турског зулума, а све су јој поубијали. На крају Станковићеве божјакиње завршавају трагично. Њихов трагичан завршетак везује се за свет природе, што се, јасно је, може повезати са поделама митског простора, према коме опасност вреба у простору који није апсолутно свој, па су тако Назу растргли вукови, Вејка умире у пољу, а Биљарница се распада у шуми.

Што се тиче Андрићевих приповедака, жене се у њима такође налазе у опасности, изван заштићеног простора. У Смрти у Синановој текији Алидеде пред смрт оживљава два догађаја, у којима га је збунила појава жене. Први пут то је мртво женско тело које је као дечак видео код плота, у башти. Трчао је према кући, према свом простору у митском кодексу. Лутао је по авлији, коју чувају авлијска врата. Једва су га натерали у кућу, али догађај није заборавио. Жену је донела река, и она ју је и однела. „У народним веровањима водени простор је осмишљен и као место на коме, док прелазе на 'онај свет', привремено бораве душе умрлих" (Бајић 2008: 32). Извори, реке и воде су нечиста места и такође се сматрају „стаништем злих демона” (Братић 1993: 28), али и душа умрлих, јер се верује да „на другом свету влада жећ” (Чајкановић 1994: 82). Други пут је реч о жени која „у белој хаљини или само у кошуљи” (Андрић 2008: 159) бежи од гонилаца.

4 Ноћ, наиме, захтева будност како би се заштитио свој простор, јер будан човек одбија од себе зле силе. Посебно је значајно бдење над мртвацем, како се он не би претворио у вампира. Постоји и веровање да ће душа покојника повести са собом душу спавача. 
У Напасти страдање је на комичан начин везано за фра Стјепана. Страдалник је, међутим, ипак, жена. Млада девојка која се успротивила патријархалном закону, и оглушила о вољу родитеља. Нису јој дали да се виђа са момком кога је заволела, а она се тајно виђала са њим. Сада се он жени другом, а њој отац прети да ће је заклати ако настави да га срамоти. Она се није само оглушила о родитељску одлуку, него и о иницијацијски ред, а то напросто не може проћи без последица. Њен бунт ту не престаје, она се одважила да легне у фратарски душек, кад већ није могла лећи са вољеним младићем. И поред свих преступа које је чинила, Андрић судбину овог лика оставља отвореном.

За разлику од ње, хаџика Ташана у новели Парапута, због свог преступа не остаје некажњена. Она се „преварила и загледала у неког лепог, чувеног са своје лепоте т. з. Ману-Грка" (Станковић 1991: 53). Говорећи о њеној казни, Станковић најпре говори о различитим начинима за кажњавање жена удовица због таквих преступа. Уколико није имала децу давали би јој „отров да га добровољно попије" (Станковић 1991: 53). Онима које имају децу одузимали би их, а њих би удали за неког слугу „блесастога, последњег у махали” (Станковић 1991: 53). Ташанина казна био је Парапута: „довели тога Парапуту и дали јој га да целог века готово затворена у кући, само њега чува и надгледа [...] И то јој је била као казна, испаштање" (Станковић 1991: 53).

Маркова мајка је, такође, кажњена за своје неверство и „ашковање у младости са неким агом” (Станковић 1991: 74), па је „пре времена, умрла због њега што га је родила таквог" (Станковић 1991: 73). Њен грех пренео се и на Марка, али и на сву његову браћу, ,jер без греха родитеља породица се лако не квари" (Станковић 1991: 75).

Свет божјака ,јасно је структуиран” (Пешикан 2005: 434), са јасним правилима и кодексима. Говорећи о жени у приповедној прози Старе Србије, Бојан Јовић каже да она „није другоразредна и једнодимензионална” (Јовић 2011: 58), него да је жена у многим случајевима „надмоћнија и мудрија од мушкараца" (Јовић 2011: 58). Стога не чуди, да је најближа свету града међу божјацима била управо Наза.

Према патријархалној култури жена је остварена једино у браку. Отуда и Назина жеља за браком. Са друге стране, девојка у Напасти је ту могућност изгубила, те јој ништа друго не преостаје него да настави борбу против патријархалних стега.

Жена је у словенској култури чуварка огњишта, док је патријархалној култури женско начело ритуално нечисто. У приповеци Наnacm проналазимо следеће речи упућене жени: „Одступи, ђаволе, од крштене душе! [...] О, ђавоље кћери! О, напасти! О, погана женска!” (Андрић 2008: 162-163). Жена 
„по схватању нашег народа, и других нама сродних народа, нпр. Германаца, има нечег демонског [...] Женски принцип инплицира у себи зло знамење” (Чајкановић 1973: 37). Марков брат, сећајући се мајчиних грехова, а дубоко скрхан Марковим речима: „Бато, срца немам” (Станковић, 1991: 74), каже: „Курво мајке, курво мајке!” (Станковић 1991: 74)

\section{3. МЕТОДИЧКО ОБРАЗЛОЖЕЬЕ}

Наставна обрада ове теме на часовима српског језика и књижевности везује се за средњу школу и била би у знаку опредељења за истраживачку наставну методу и групни облик рада.

Истраживачка наставна метода подразумева висок степен самосталности ученика и као таква доприноси уједначавању улога наставника и ученика, што доприности већој успешности комуникације. Циљ коме тежи модерна настава овом методом је све ближи, а то је стварање „симетричне поделе улога наставника и ученика" (Милетић 2005: 52), с обзиром на то да је она до сада ишла у корист наставника. Улога наставника у овој наставној методи је заиста специфична и као таква захтева додатно проучавање. Комуникацијска компетентност наставника у овој методи стављена је на тест. Наставник у њој индиректно утиче на комуникацију, охрабрујући ученике у изношењу њиховог мишљења и у критичком вредновању: „Учитељи су мање они који уче, јер знање се може стицати на разне начине, а више они који помажу да се научи" (Ненадић 1997: 46).

Наиме, најутицајнија улога наставника у овој методи огледа се у њеној првој фази која подразумева уводну реч наставника, стварање проблемске ситуације и постављање хипотезе.

Наставниково излагање требало би да буде прожето другим методама, као што су „краћи разговори са ученицима, читање литерарних или стручних прилога, коришћење чулног представљања и бележење битних података на табли” (Николић 2009: 45). Тако предавање „постаје занимљивије и не прети му опасност од једноличности и прераног замарања ученика" (Николић 2009: 45).

Потребно је допустити ученицима да постављају питања у току наставниковог излагања. Неопходно је у настави често стварати услове у којима ученици постављају питања о свему што их интересује: „Култура постављања питања је особина радозналог духа" (Маринковић 2003: 39). Изузетно је важно да се наставник обраћа ученицима, а не разреду, да би комуникација била успешна. 
Уводна фаза има изузетан значај за истраживачку методу, јер ученицима предочава проблеме и задатке којима ће се надаље, самостално (индивидално) или у групи, бавити. Уколико дође до превеликог комуникацијског шума могуће је да истраживање буде неуспешно. Дакле, уколико уводна реч не буде комуникабилна, даља комуникација ће бити „псеудокомуникација” (Милетић 2005: 58), тј. доћи ће до ситуације „настава ради наставе” (Милетић 2005: 58).

Након наведене уводне фазе, главну улогу у овој методи преузимају ученици. Прво следи трагање за решењима, самостално, у паровима или групама, а потом представљање резултата истраживања, извођење закључака о њима и на крају долази дискусија о резултатима истраживања.

Што се тиче представљања резултата они се уклапају у један од основних задатака креативне наставе, а то је „стваралачка примена наставних монолога” (Николић 2009: 44), која се огледа „у подстицању ученика да све чешће долазе у улогу наставника" (Николић 2009: 44). На тај начин се подстиче сазнајна делатност.

Монолошко излагање ученика је битан елеменат креативне наставе. Далеко је сврховитије од њиховог дијалошког испољавања. У излагању учествују сви чланови групе како би се избегло истицање само појединих чланова и „спутавање активности осталих ученика” (Николић 2009: 49). „Корисно је да сваки члан групе извештава о свом свом делу обављеног посла" (Николић 2009: 49).

Осим тога, са комуниколошке стране важну улогу игра и дискусија о добијеним резултатима. Разговор је основни инструмент образовања и васпитања у педагошком раду. У уводној фази имали смо разговор наставника и ученика. Последња фаза би могла бити организована као дискусија ученика о добијеним резултатима. Непосредно пре ове фазе наставник би требало да упозна ученике са неколико основних правила комуникације. Њихова комуникација, као и комуникација наставника и ученика, али и свака друга комуникација, треба да буде отворена, центрирана, демократска, квалитетна, креативна, обострана, искрена и слободна. То није комуникација која је зависна од других, која је усмерена против других, вођена за друге, површна или дистанцирана. То је комуникација са другима. Осим тога треба их упознати са основама добре повратне информације, како би успешно савладали ову вештину. 


\section{1. МЕТОДИЧКИ КОРАЦИ}

Две недеље пре обраде ове теме ученици ће бити подељени у групе, а свака од њих добиће своје истраживачке задатке и потребну литературу за њихову обраду. Што се тиче група, њихови чланови „самостално, а свакако и уз консултовање са професором, одређују вођу групе, деле задужења, договарају се, помажу и припремају заједнички извештај” (Николић 2009: 131). Један час недељно треба посветити праћењу резултата до којих су групе дошле. Након истраживања и трагања за решењима, групе би на часовима српског језика и књижевности представљале своје резултате. Свака група имала би за то по један школски час. Монолошко излагање ученика је битан елеменат креативне наставе. Неопходно је омогућити ученицима да износе повратну информацију о раду других група, али и самокритику. Последњи час обраде представљао би заједнички рад група на повезивању приповедака Иве Андрића и Борисава Станковића и прављењу заједничког извештаја. Након истраживања, организовати угледни час на коме би биле представљене предности и мане истраживачке наставне методе, на основу искуства ученика и наставника.

\section{2. ИСТРАЖИВАЧКИ ЗАДАЦИ}

3.2.1. Прва група:

1. Прочитати приповетке Hanacm и Смрт у Синановој текији Иве Андрића.

2. Прочитати одреднице Боја, Камен, Ноћ, Време, Месец из енциклопедијског речника Словенска митологија.

3. Које елементе из одреднице препознајете у приповеткама? Образложити одговор.

Додатна литеаратура:

Детелић, М. (2000). “Жена на капији“. Свеске задужбине Иве Андрића 17: 245-260.

Братић, Д. (1993). Глуво доба. Београд: Плато.

\subsection{2. Друга група:}

1. Прочитати збирку приповедака Божји људи Борисава Станковића.

2. Прочитати одреднице Боја, Камен, Ноћ, Време, Месеи из енциклопедијског речника Словенска митологија.

3. Које елементе из одреднице препознајете у приповеткама? Образложити одговор. 
Додатна литература:

Братић, Д. (1993). Глуво доба. Београд: Плато.

Бајић, Љ. (2008). “Фолклорни мотиви у збирци Божји људи Борисава Станковића“. Зборник Матице српске за славистику 73: 25-34.

\subsection{3. Трећа група:}

1. Прочитати збирку приповедака Божји људи Борисава Станковића.

2. Урадити анализу женских ликова - божјакиња у збирци. Илустровати цитатима из дела.

Додатна литература:

Јовић, Б. (2001). “О лику жене и женским ликовима у приповеци старе Србије“, у Кюижевност старе и јужне Србије, ур. В. Цветановић (Београд: Институт за књижевност и уметност : Балканолошки институт САНУ): 57-63.

Чолак, Б. (2011). “Типско у приказу јунакиња збирке Божји људи Борисава Станковића“, у Зборник Српски језик, книжевност, уметност. Жене: род, идентитет, књижевност, ур. Д. Бошковић (Крагујевац: Филолошко-уметнички факултет: Скупштина града : Интерагент): 301-311.

Пешикан-Љуштановић, Љ. (2005). Борисав Станковић - између традиције и модерности, Зборник Матище српске за књижевност и језик 53: $431-464$.

\section{ЛИТЕРАТУРА:}

Андрић, И. (2008). Сабране приповетке, Београд: Завод за издавање уџбеника.

Бајић, Љ. (2008). “Фолклорни мотиви у збирци Божји људи Борисава Станковића". Зборник Матице српске за славистику 73: 25-34.

Белова, О. В. (2001). "Боја“, у Словенска митологија - енциклопедијски речник, ур. Љ. Раденковић и С. Толстој (Београд: Zepter book world): 43-44.

Братић, Д. (1993). Глуво доба. Београд: Плато.

Чајкановић, В. (1973). „Гостопримство и теофанија”, у Мит и религија у Срба, ур. В. Ђурић (Београд: Српска књижевна задруга : Култура): 64-94.

Чајкановић, В. (1994). “Домаћа религија и култ”, у Стара српска религија и митологија, ур. Б. Живојиновић, Р. Цајић, В. Јанковић, В. Ђурић 
(Београд: Српска књижевна задруга : Београдски графичко-издавачки завод): 72-160.

Чолак, Б. (2011). “Типско у приказу јунакиња збирке Божји људи Борисава Станковића", у Зборник Српски језик, књижевност, уметност. Жене: род, идентитет, књижевност, ур. Д. Бошковић (Крагујевац : Филолошко-уметнички факултет : Скупштина града : Интерагент): $301-311$.

Деретић, J (2007). Историја српске књижевности. Зрењанин: Sezam book. Детелић, М. (2000). “Жена на капији”. Свеске задужбине Иве Андрића 17: $245-260$.

Илић, П. (2006). Српски језик и кюижевност у наставној теорији и пракси. Нови Сад: Змај.

Гајић, О (2009). “Креативно решавање проблема у настави књижевности”, у Тумачења књижевног дела и методика наставе 2, ур. О. Радуловић (Нови Сад: Филозофски факултет : Орфеј): 295-322.

Илић, П. (2009). “Последице кризе читања у настави”, у Тумачења књижевног дела и методика наставе 2, ур. О. Радуловић (Нови Сад: Филозофски факултет : Орфеј): 7-20.

Јовић, Б. (2001). “О лику жене и женским ликовима у приповеци Старе Србије”, у Кюижевност старе и јужне Србије, ур. В. Цветановић (Београд: Институт за књижевност и уметност : Балканолошки институт САНУ): 57-63.

Левкиевска, J. Ј. (2001). "Камен“, у Словенска митологија-енцииклопедијски речник, ур. Љ. Раденковић и С. Толстој (Београд: Zepter book world): 257-259.

Мајл, А. (1968). Креативност у настави. Сарајево: Свјетлост.

Маринковић, С. (2003). Методика креативне наставе српског језика и кюижевности. Београд: Креативни центар.

Милетић, М. (2005). Основе комуникологије. Јагодина: Педагошки факултет. Ненадић, М. (1997). Нови дух образовања. Београд: Просвета.

Николић, М. (2009). Методика наставе српског језика и књижевности. Београд: Завод за уџбенике.

Пантић, Н. (2010). Наставници су битни. Београд: Завод за уџбенике.

Плотникова, А. А. (2001). "Ноћ“, у Словенска митологија-енцииклопедијски речник, ур. Љ. Раденковић и С. Толстој (Београд: Zepter book world): 389-390.

Пешикан-Љуштановић, Љ. (2005). “Борисав Станковић - између традиције и модерности”. Зборник Матицее српске за књижевност и језик 53: $431-464$. 
Радуловић, О. (2011). Нове научне методологије у настави књижевности. Нови Сад: Орфеј.

Станковић, Б. (1991). Божји људи. Београд: „Београд“.

Толстој”, С. М. (2001). "Време“, у Словенска митологија - енциклопедијски речник, ур. Љ. Раденковић и С. Толстој (Београд: Zepter book world): $100-102$.

Толстојб, С. М. (2001). "Месец“, у Словенска митологија - енциклопедијски речник, ур. Љ. Раденковић и С. Толстој (Београд: Zepter book world): 354-355.

\title{
Jovana Davidović
}

\author{
BORISAV STANKOVIĆ AND IVO ANDRIĆ \\ IN THE LIGHT OF THE NEW CURRICULUM STUDIES
}

\section{Summary}

The paper comprises two parts: the analytical-interpretative and the methodical part. The focus of the first part of the paper is a comparative study of The godly people by Borisav Stanković and Temptation and Death in Sinan's tekke by Ivo Andrić. By means of a comparative analysis, the paper examines the impact of the mythic image of the world and the traditional culture in these works. The paper is primarily focused on the impact of the mythic time and space, the basic categories of the mythic image of the world. Traces of traditional cultures are found in the binary opposition of black and white, but also in the protective role of the stone and its ability to bind itself to the souls of the dead. The paper also compares Stanković's and Andrić's godly people. At the end "stand" women at the gate.

The paper aims to provide an impetus for the creation and modernization of the subject the Serbian Language and Literature, with the goal of emphasizing the principle of a scientific approach in the contemporary teaching context and encouraging active and creative reading. Through the application of contemporary findings in teaching methodology, this paper fights against every scheme, stereotype and rote learning, bound by the artistic essence of literature.

Key words: mythic space, mythic time, white-black, stone, godly men, women at the gate, teaching, methodology. 